Research article

Open Access

\title{
Association of cerebrospinal fluid anti-ribosomal P protein antibodies with diffuse psychiatric/neuropsychological syndromes in systemic lupus erythematosus
}

\author{
Shunsei Hirohata ${ }^{1}$, Yoshiyuki Arinuma², Maki Takayama² and Taku Yoshio $^{3}$
}

\author{
1Department of Rheumatology and Infectious Disease, Kitasato University School of Medicine, 1-15-1 Kitasato, Sagamihara, Kanagawa 228-8555, \\ Japan \\ 2Department of Internal Medicine, Teikyo University School of Medicine, 2-11-1 Kaga, Itabashi-ku, Tokyo 173-8605, Japan \\ ${ }^{3}$ Division of Rheumatology and Clinical Immunology, Jichi Medical University, 3311-1 Yakushiji, Shimotsuke, Tochigi 329-0498, Japan \\ Corresponding author: Shunsei Hirohata, shunsei@med.teikyo-u.ac.jp
}

Received: 28 Jul 2006 Revisions requested: 9 Aug 2006 Revisions received: 5 Mar 2007 Accepted: 2 May 2007 Published: 2 May 2007

Arthritis Research \& Therapy 2007, 9:R44 (doi:10.1186/ar2184)

This article is online at: http://arthritis-research.com/content/9/3/R44

(c) 2007 Hirohata et al.; licensee BioMed Central Ltd.

This is an open access article distributed under the terms of the Creative Commons Attribution License (http://creativecommons.org/licenses/by/2.0), which permits unrestricted use, distribution, and reproduction in any medium, provided the original work is properly cited.

\begin{abstract}
We explored the relationship of antibodies to the whole ribosomal $\mathrm{P}$ proteins ( $\mathrm{P} 0, \mathrm{P} 1$, and $\mathrm{P} 2$ ) in cerebrospinal fluid (CSF) with diffuse psychiatric/neuropsychological syndromes in systemic lupus erythematosus (SLE). CSF samples were obtained from 71 SLE patients (52 patients with diffuse psychiatric/neuropsychological syndromes [diffuse NP-SLE] and 19 patients with neurological syndromes or peripheral neuropathy [focal NP-SLE]) as well as from 24 patients with non-inflammatory neurological disease. Immunoglobulin G ( $\lg G)$ antibodies to the $\mathrm{C}$-terminal 22-amino acid ribosomal $P$ synthetic peptide (anti- $\mathrm{P}_{\mathrm{C} 22}$ ) and those to purified bovine ribosomal $\mathrm{P}$ proteins ( $\mathrm{P} 0, \mathrm{P} 1$, and $\mathrm{P} 2$ ) (anti-whole $\mathrm{P}$ ) were determined by enzyme-linked immunosorbent assay; affinitypurified IgG anti- $P_{\mathrm{C} 22}$ were used as the standard. The concentrations of antibodies to epitopes other than the Cterminal 22 amino acids of ribosomal $P$ proteins were calculated by subtracting anti- $\mathrm{P}_{\mathrm{C} 22}$ from anti-whole $\mathrm{P}$ (anti- $\left.\mathrm{P}_{\mathrm{EX} . \mathrm{C} 22}\right)$. CSF
\end{abstract}

anti-whole $P$ levels were significantly elevated in diffuse NP-SLE compared with focal NP-SLE or control patients. By contrast, there were no significant differences in CSF anti- $P_{\mathrm{C} 22}$ levels among the three groups. Of note, CSF anti- $P_{E X . C 22}$ levels were significantly elevated in diffuse NP-SLE compared with the other two groups. CSF anti- $P_{E X . C 22}$ levels were not significantly correlated with CSF anti- $\mathrm{P}_{\mathrm{C} 22}$ levels, but with CSF antibodies against the recombinant ribosomal $\mathrm{PO}$ protein lacking the $\mathrm{C}$ terminal 22 amino acids (C22-depleted rPO). Moreover, levels of CSF anti-P EX.C22 $_{2}$ or CSF anti-C22-depleted rP0, but not CSF anti- $P_{C 22}$, were significantly correlated with CSF anti-neuronal cell antibodies (anti-N). These results indicate that CSF IgG antibodies to the epitopes other than the C-terminal 22 amino acids of ribosomal $\mathrm{P}$ proteins, which might contain one of the major targets of CSF anti-N, are associated with the development of diffuse NP-SLE.

\section{Introduction}

Central nervous system (CNS) involvement is a relatively common and serious complication of systemic lupus erythematosus (SLE) [1,2]. Previous studies have demonstrated the association of serum antibodies directed against the C-terminal 22-amino acid sequences of ribosomal $P$ protein (anti-
$\mathrm{P}_{\mathrm{C} 22}$ ) with CNS involvement in patients with SLE (neuropsychiatric SLE [NP-SLE]), especially diffuse psychiatric/neuropsychological syndromes (diffuse NP-SLE) [3-5]. However, the mechanism by which serum anti- $\mathrm{P}_{\mathrm{C} 22}$ leads to the development of diffuse NP-SLE has not yet been elucidated. In fact, the role of anti- $\mathrm{P}_{\mathrm{C} 22}$ in the cerebrospinal fluid (CSF) in the

$\mathrm{ACR}=$ American College of Rheumatology; anti-C22-depleted rPO = antibodies directed against recombinant ribosomal P0 protein lacking the Cterminal 22 amino acids; anti-N = anti-neuronal cell antibodies; anti- $\mathrm{P}_{\mathrm{C} 22}=$ antibodies directed against the $\mathrm{C}$-terminal 22 -amino acid sequences of ribosomal $\mathrm{P}$ protein; anti- $\mathrm{P}_{\mathrm{EX} . \mathrm{C} 22}=$ autoantibodies directed against the ribosomal $\mathrm{P}$ protein epitopes other than the $\mathrm{C}$-terminal 22 -amino acid sequence; anti-whole $\mathrm{P}=$ antibodies to the whole ribosomal $\mathrm{P}$ proteins; $\mathrm{C} 22$-depleted $\mathrm{rPO}=$ recombinant ribosomal $\mathrm{PO}$ fusion protein lacking the $\mathrm{C}$ terminal 22 amino acids; CNS = central nervous system; CSF = cerebrospinal fluid; ELISA = enzyme-linked immunosorbent assay; HSA = human serum albumin; IgG = immunoglobulin G; IL-6 = interleukin-6; NMDA = N-methyl-d-aspartate; non-CNS SLE = systemic lupus erythematosus without neuropsychiatric manifestations; NP-SLE = neuropsychiatric systemic lupus erythematosus; $\mathrm{OD}_{492}=$ optical density at $492 \mathrm{~nm} ; \mathrm{PBS}=$ phosphatebuffered saline; SLE $=$ systemic lupus erythematosus. 
pathogenesis with diffuse NP-SLE or even their presence in the CSF remains uncertain. Thus, Golombek and colleagues [6] detected the presence of CSF anti- $\mathrm{P}_{\mathrm{C} 22}$ in all four of the patients with lupus psychosis in their studies, whereas others did not $[3,4,7]$.

On the other hand, autoantibodies, which react with the neuronal cell lines or brain tissue, have been reported in the sera of patients with NP-SLE [8-10]. However, they have been shown to be present in SLE patients with no clinical evidence of CNS involvement [10]. In fact, in a cross-sectional study of SLE patients, no significant association was found between serum lymphocyte/brain cross-reacting antibodies and NPSLE (present in $32 \%$ of cases with NP-SLE and $23 \%$ of those without NP-SLE) [10]. Of note, using a radioimmunoassay with the SK-N-SH neuroblastoma cell as a target, Bluestein and colleagues [11] demonstrated that immunoglobulin $\mathrm{G}$ ( $\operatorname{lgG}$ ) anti-neuronal cell antibodies (anti-N) were present in much higher concentrations in the CSF from patients with active NP-SLE than in the CSF from SLE patients without active CNS involvement. Using a cell enzyme-linked immunosorbent assay (ELISA) with SK-N-MC neuroblastoma cell lines fixed with paraformaldehyde, we also confirmed that CSF IgG anti-N levels were significantly elevated in patients with diffuse NP-SLE compared with those in SLE patients without diffuse NP-SLE [7]. However, the fine epitopes to which CSF anti-N were directed have not yet been delineated.

The presence of the immunodominant C-terminal epitope of ribosomal $\mathrm{P}$ proteins was demonstrated to be present on the surface of human neuroblastoma cells [12]. However, CSF anti- $\mathrm{P}_{\mathrm{C} 22}$ could be detected in only a fraction of patients with diffuse NP-SLE, whereas almost all the patients with diffuse NP-SLE expressed CSF anti-N [7]. Of note, previous studies also demonstrated the presence of a $38-\mathrm{kDa}$ protein that is closely related to, or identical with, ribosomal $\mathrm{PO}$ protein in purified human plasma membranes [12]. In addition, it has been shown that autoantibodies directed against the ribosomal $\mathrm{P}$ proteins are not only directed against the common $\mathrm{C}$ terminal 22 amino acids, but against the $\mathrm{N}$-terminal sequence of the ribosomal P2 or P1 proteins [13]. In fact, recent studies have revealed that measurement of CSF IgG anti-ribosomal $P$ protein antibodies with Western blotting using purified ribosomes, containing whole ribosomal $\mathrm{P} 0, \mathrm{P} 1$, and $\mathrm{P} 2$ proteins, was more sensitive [14]. Because ribosomal PO protein contains epitopes other than the C-terminal 22 amino acids, it is possible that CSF from patients with diffuse NP-SLE contains antibodies to such epitopes. The current studies, therefore, were carried out to compare the CSF levels of antibodies to the whole ribosomal $P$ proteins (anti-whole $P$ ) in patients with diffuse NP-SLE and in patients with focal NP-SLE or non-SLE non-inflammatory neurological disorders.

\section{Materials and methods \\ Patients and samples}

One hundred and three patients with SLE were included in the present study. All patients fulfilled the American College of Rheumatology (ACR) 1982 revised criteria for the classification of SLE [15]. Of the 103 patients with SLE, 52 showed diffuse psychiatric/neurological syndromes (diffuse NP-SLE) according to the 1999 ACR definition of NP-SLE [16], 19 patients showed CNS manifestations other than diffuse NPSLE (focal NP-SLE), and 32 patients showed no CNS manifestations (non-CNS SLE). Ten of the 52 patients with diffuse NP-SLE also presented seizures. Because of the difficulties in confirming the neurological diagnosis and in assigning the cause to SLE, we defined NP-SLE as (a) the presence of neuropsychiatric manifestations and (b) the elevation of CSF Ig indices $[17,18]$ and/or the elevation of CSF interleukin-6 (IL-6) levels [19]. Thus, the 52 patients all showed increased CSF Ig indices and/or CSF IL-6 in the present study. In addition, 24 patients with non-SLE non-inflammatory neurological diseases ( 9 cerebrovascular diseases, 8 cervical spondylosis, 4 degenerative diseases, 2 diabetic neuropathy, and 1 epilepsy) were studied as a control. The 127 patients all gave informed consent, and the study was approved by the institutional ethical committee of Teikyo University School of Medicine (Tokyo). The detail and demographic features of the 127 patients are shown in Table 1. CSF specimens were obtained by a lumbar puncture when the patients showed active disease. These samples were kept frozen at $-20^{\circ} \mathrm{C}$ until assayed. All assays were performed without knowledge of the diagnosis or clinical presentations.

Human anti- $\mathbf{P}_{\mathbf{C 2 2}}$ sera and affinity purification of anti- $\mathbf{P}_{\mathbf{C 2 2}}$ $\lg G$ fractions were purified from the anti- $P_{\mathrm{C} 22}$-positive sera of SLE patients by means of a protein G-Sepharose 4FF column (Amersham Pharmacia Biotech, now part of GE Healthcare, Little Chalfont, Buckinghamshire, UK). Anti- $\mathrm{P}_{\mathrm{C} 22}$ were purified from the $\lg G$ fractions of SLE sera by means of an $N$-hydroxysuccinimide-activated Sepharose HP column (GE Healthcare) coupled with synthetic ribosomal $P$ peptide-human serum albumin (HSA) conjugates as previously described [20]. Anti$\mathrm{P}_{\mathrm{C} 22}$ thus purified reacted strongly with ribosomal $\mathrm{P}$ peptideHSA conjugates, but not with HSA alone in an ELISA. It was also confirmed on Western blot analysis that purified anti- $\mathrm{P}_{\mathrm{C} 22}$ reacted with native ribosomal $P$ proteins ( $P 0, P 1$, and $P 2$ ) (data not shown).

Measurement of autoantibodies to ribosomal $\mathbf{P}$ proteins Antibodies for the C-terminal 22-amino acid ribosomal $\mathrm{P}$ synthetic peptide (anti- $\mathrm{P}_{\mathrm{C} 22}$ ) in sera and CSF and those for purified whole ribosomal $P$ proteins (anti-whole $P$ ) in CSF were determined by specific ELISA using the highly purified synthetic C-terminal 22-amino acid ribosomal $P$ peptide conjugated to HSA as an antigen as previously described [5] and highly purified bovine ribosomal $\mathrm{P}$ proteins ( $\mathrm{P} 0, \mathrm{P} 1$, and $\mathrm{P} 2$ ) (purity of more than 90\%) (Arotec Diagnostics Limited, Wel- 
Table 1

\begin{tabular}{|c|c|c|c|}
\hline Diagnosis & Number of patients & Gender (male/female) & Age in years (mean $\pm S D)$ \\
\hline SLE & 103 & & \\
\hline Diffuse NP-SLE & 52 & $4 / 48$ & $37.8 \pm 14.2$ \\
\hline Acute confusional state & 20 & & \\
\hline Anxiety disorder & 3 & & \\
\hline Cognitive dysfunction & $10^{a}$ & & \\
\hline Mood disorder & $12^{b}$ & & \\
\hline Psychosis & 7 & & \\
\hline Focal NP-SLE & 19 & $2 / 17$ & $39.0 \pm 14.8$ \\
\hline Cerebrovascular disease & 6 & & \\
\hline Headache & 2 & & \\
\hline Movement disorder & 1 & & \\
\hline Seizure disorder & 6 & & \\
\hline Polyneuropathy & 4 & & \\
\hline Non-CNS SLE & 32 & $3 / 29$ & $42.7 \pm 13.9$ \\
\hline Non-SLE control & 24 & $22 / 2$ & $48.0 \pm 13.7$ \\
\hline
\end{tabular}

aOne patient also presented mood disorder. bOne patient also presented cognitive dysfunction. Non-CNS SLE, systemic lupus erythematosus without neuropsychiatric manifestations; NP-SLE, neuropsychiatric systemic lupus erythematosus; SD, standard deviation; SLE, systemic lupus erythematosus.

lington, New Zealand). Antibodies for the epitope representing regions of the ribosomal $P$ proteins other than $\mathrm{P}_{\mathrm{C} 22}$ were similarly determined by ELISA using recombinant ribosomal PO fusion protein lacking the C-terminal 22 amino acids (C22depleted rPO) as previously described [21].

Briefly, wells of a 96-well microtiter plate were coated with ribosomal $\mathrm{P}$ peptide-HSA conjugates at $15 \mu \mathrm{g} / \mathrm{ml}$ or highly purified bovine ribosomal $P$ proteins at $1.0 \mu \mathrm{g} / \mathrm{ml}$ in phosphate-buffered saline (PBS) $(\mathrm{pH} 7.2)$ or $\mathrm{C} 22$-depleted $\mathrm{rPO}$ at $5 \mu \mathrm{g} / \mathrm{ml}$ in $6 \mathrm{M}$ urea/10 mM Tris- $\mathrm{HCl}(\mathrm{pH} 7.5)$ with $2 \mathrm{mM} 2-$ mercaptoethanol (coating buffer) at $4^{\circ} \mathrm{C}$ overnight. Each well was then overcoated with Block Ace (Dainippon Pharmaceutical, Osaka, Japan), diluted 1:4 with PBS. Prior to being added to the antigen-coated wells, serum and CSF samples were usually diluted $1: 200$ and 1:2, respectively, in PBS containing $1 \%$ bovine serum albumin (Miles, now part of Bayer Corp., Emeryville, CA, USA). Bound antibody was detected with peroxidase-conjugated $F\left(a b^{\prime}\right)_{2}$ fragments of goat antihuman IgG (MP Biochemicals, Solon, OH, USA). After incubation with substrate solution containing $60 \mathrm{mg}$ of o-phenylenediamine and $10 \mu \mathrm{l}$ of $30 \% \mathrm{H}_{2} \mathrm{O}_{2}$ in $100 \mathrm{ml}$ of $0.05 \mathrm{M}$ citrate phosphate buffer $(\mathrm{pH} 4.8)$ at $37^{\circ} \mathrm{C}$ for 30 minutes, the reaction was stopped by addition of $5 \mathrm{~N} \mathrm{H}_{2} \mathrm{SO}_{4}$, and the absorbance (optical density) at $492 \mathrm{~nm}\left(\mathrm{OD}_{492}\right)$ was read with a two-wave- length microplate photometer (MTP-120; Corona Electric Co., Ltd., Ibaraki, Japan). Determinations of $\mathrm{OD}_{492}$ were normalized to affinity-purified anti- $P_{\mathrm{C}_{22}}$ such that anti- $\mathrm{P}_{\mathrm{C} 22}$ and anti-whole $P$ activity might be converted to micrograms per milliliter of IgG. Antibodies directed against C22-depleted rPO (anti-C22depleted rPO) were expressed by arbitrary unit designation using a standard serum.

Non-specific binding activities to HSA for anti- $\mathrm{P}_{\mathrm{C} 22}$ or those to wells with PBS alone or coating buffer alone for anti-whole $\mathrm{P}$ or anti-C22-depleted $\mathrm{rPO}$ were also determined in reference to the standard curves for binding activities to ribosomal $P$ peptide $\left(\mathrm{P}_{\mathrm{C} 22}\right)$-HSA conjugates, highly purified ribosomal $\mathrm{P}$ proteins, or $\mathrm{C} 22$-depleted $\mathrm{rPO}$. The specific anti- $\mathrm{P}_{\mathrm{C} 22}$, anti-whole $\mathrm{P}$, or anti-C22-depleted $\mathrm{rPO}$ activities were thus determined by subtracting the values for the non-specific binding activity from those for binding activity to $\mathrm{P}_{\mathrm{C} 22}-\mathrm{HSA}$ conjugates or to highly purified ribosomal $\mathrm{P}$ proteins or $\mathrm{C} 22$-depleted $\mathrm{rPO}$. The intraassay and interassay variances (coefficient of variation values) for anti-whole $\mathrm{P}$ were $13.8 \%$ and $15.7 \%$, respectively, and those for anti- $\mathrm{P}_{\mathrm{C} 22}$ were previously described [7].

\section{Measurement of anti-N}

Anti-N in the CSF samples were determined by a cell ELISA using human neuroblastoma cell line SK-N-MC as previously 
(a)

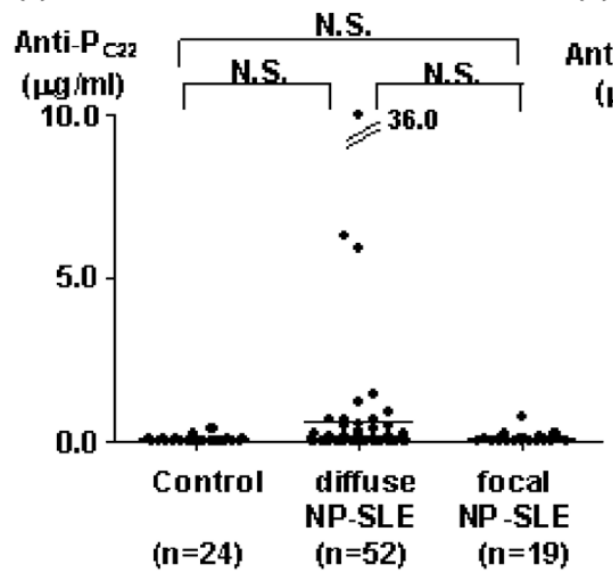

(b)

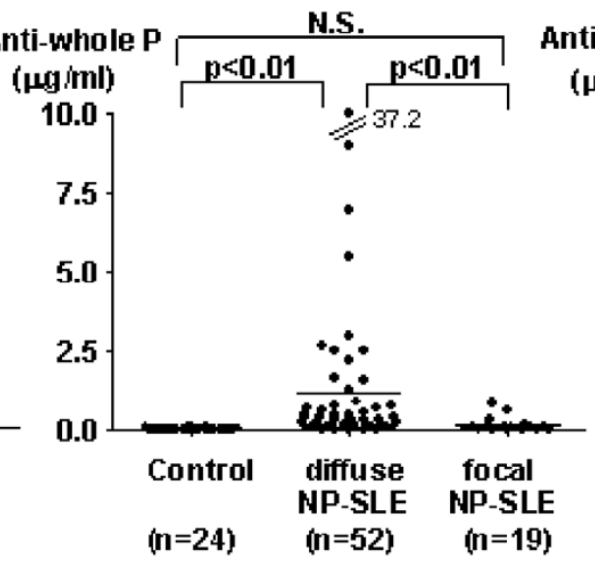

(c)

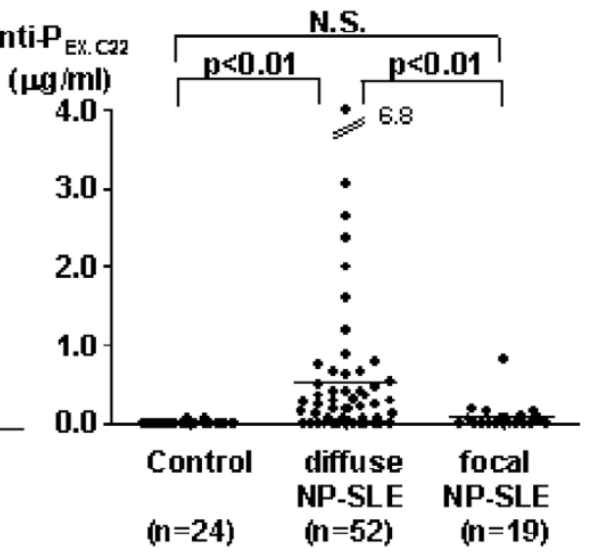

Cerebrospinal fluid antibodies to various components of ribosomal P proteins. CSF antibodies to the C-terminal 22-amino acid sequence of ribosomal $\mathrm{P}$ protein (anti- $\mathrm{P}_{\mathrm{C} 22}$ ), highly purified ribosomal $\mathrm{P}$ proteins (anti-whole $\mathrm{P}$ ), and epitopes other than the $\mathrm{C}$-terminal 22-amino acid sequence (anti$\left.\mathrm{P}_{\mathrm{EX} . \mathrm{C} 22}\right)$. Anti- $\mathrm{P}_{\mathrm{C} 22}(\mathrm{a})$, anti-whole $\mathrm{P}(\mathrm{b})$, and anti- $\mathrm{P}_{\mathrm{EX} . \mathrm{C} 22}(\mathrm{c})$ in CSF from patients with non-inflammatory neurological diseases (Control), with diffuse neuropsychiatric systemic lupus erythematosus (NP-SLE), or with focal NP-SLE were compared. Horizontal lines indicate the mean values. Statistical analysis was performed by Kruskal-Wallis test with multiple comparisons (Scheffé's method). CSF, cerebrospinal fluid; N.S., not significant.

described [7]. Briefly, SK-N-MC cells were seeded at a density of $5 \times 10^{4}$ per well in wells of a flat-bottomed 96-well tissue culture plate (no. 3596; Costar, now part of Corning Life Sciences, Acton, MA, USA) for 48 hours, after which the cells were fixed with 1\% paraformaldehyde in PBS for 5 minutes at $37^{\circ} \mathrm{C}$. After three washes with PBS containing $0.05 \%$ Tween $20,50 \mu$ l of the appropriately diluted samples or various concentrations of standard sera were added and the plates were incubated for 1 hour at $37^{\circ} \mathrm{C}$. Bound IgG anti-N were detected with peroxidase-conjugated $F\left(a b^{\prime}\right)_{2}$ fragments of goat anti-human IgG as previously described [7]. Determination of $\mathrm{OD}_{492}$ was normalized to standard sera for anti-N obtained from patients with diffuse NP-SLE such that anti-N activity might be converted to an arbitrary unit scale. The concentration of anti- $\mathrm{N}$ that produced half of the maximal absorbance at $492 \mathrm{~nm}$, given by the saturating concentration of anti$\mathrm{N}$ in the cell ELISA plate, was arbitrarily defined as $1 \mathrm{U} / \mathrm{ml}$ [7].

\section{Statistical analysis}

Differences in CSF anti- $P_{\mathrm{C} 22}$, anti-whole $\mathrm{P}$, anti- $\mathrm{P}_{\mathrm{EX} . \mathrm{C22}}$, and anti-C22-depleted rPO among various groups were analyzed by Kruskal-Wallis test with multiple comparison (Scheffe's method). The correlation of anti- $P_{C 22}$ levels with anti- $P_{E X . C 22}$ or anti-C22-depleted rPO levels and the correlation of anti-N levels with anti- $P_{\mathrm{C} 22}$, anti- $P_{E X . C 22}$, or anti-C22-depleted rPO levels were evaluated by Spearman rank correlation test. Differences in serum anti- $P_{C 22}$, anti-whole $P$, and anti- $P_{E X . C 22}$ levels between non-CNS SLE and NP-SLE were analyzed by Welch's $t$ test.

\section{Results}

Initial experiments examined CSF anti- $\mathrm{P}_{\mathrm{C} 22}$ levels in the three groups of patients. Although anti- $\mathrm{P}_{\mathrm{C} 22}$ levels in CSF appeared to be higher in diffuse NP-SLE, there were no significant differences in their levels among the three groups, including diffuse NP-SLE, focal NP-SLE, and non-inflammatory neurological control (Figure 1a). The results therefore confirm the previous observation that CSF anti- $\mathrm{P}_{\mathrm{C} 22}$ might not be prevalent in diffuse NP-SLE. By contrast, anti-whole $P$ levels in CSF from patients with diffuse NP-SLE were significantly elevated compared with those from patients with focal NP-SLE or with noninflammatory neurological diseases (Figure 1b). In addition, it should be noted that CSF anti-whole $P$ levels were significantly higher than CSF anti- $\mathrm{P}_{\mathrm{C} 22}$ levels in 67 patients with diffuse NP-SLE and focal NP-SLE $(P<0.0001$ as evaluated by Wilcoxon signed rank test). These results suggest that in addition to anti- $\mathrm{P}_{\mathrm{C} 22}$, CSF from patients with NP-SLE might contain autoantibodies that recognize ribosomal $\mathrm{P}$ protein epitopes other than the $\mathrm{C}$-terminal 22-amino acid sequence.

To explore in detail the prevalence of the autoantibodies directed against the ribosomal $P$ protein, epitopes other than the C-terminal 22-amino acid sequence (anti- $\mathrm{P}_{\text {EX.C22 }}$ ) were calculated by subtracting anti- $\mathrm{P}_{\mathrm{C} 22}$ from anti-whole $\mathrm{P}$. As can be seen in Figure 1c, anti- $P_{\text {EX.C22 }}$ levels in CSF from patients with diffuse NP-SLE were significantly elevated compared with those from patients with focal NP-SLE or with non-inflammatory neurological diseases. As shown in Figure 2, there was no significant correlation between CSF anti- $\mathrm{P}_{\mathrm{C} 22}$ and CSF

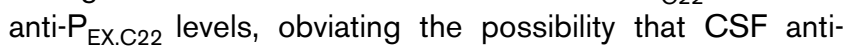
$P_{\text {EX.C22 }}$ activities might result from contamination of CSF anti$\mathrm{P}_{\mathrm{C} 22}$ in patients with SLE. These results indicate that autoantibodies directed against ribosomal $\mathrm{P}$ protein epitopes other than the C-terminal 22-amino acid sequence are strongly associated with the development of diffuse NP-SLE. Moreover, the data indicate that the expression of such 
Figure 2

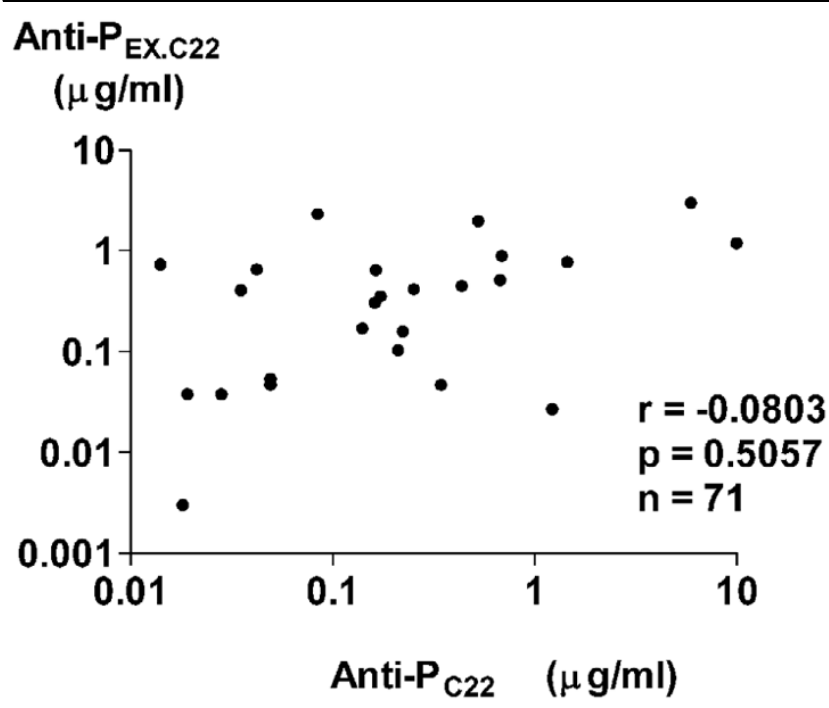

Correlation between autoantibodies to various components of ribosomal $\mathrm{P}$ proteins. The correlation between antibodies to the $\mathrm{C}$-terminal 22-amino acid sequence of ribosomal $P$ protein (anti- $P_{\mathrm{C}_{22}}$ ) and those to the ribosomal $\mathrm{P}$ protein epitopes other than the $\mathrm{C}$-terminal 22-amino acid sequence (anti- $P_{E X . C 22}$ ) in cerebrospinal fluid from patients with systemic lupus erythematosus (SLE), including 52 patients with diffuse neuropsychiatric SLE (NP-SLE) and 19 patients with focal NP-SLE, was analyzed. Statistical analysis was performed by Spearman rank correlation test.

autoantibodies in CSF is not related to the presence of anti$\mathrm{P}_{\mathrm{C} 22}$ in CSF.

To confirm the presence of autoantibodies to ribosomal P protein epitopes other than the $\mathrm{C}$-terminal 22-amino acid sequence, IgG antibodies to recombinant ribosomal PO protein lacking the $\mathrm{C}$-terminal 22 amino acids (C22-depleted rP0) were examined in CSF from 65 SLE patients with neuropsychiatric manifestations. Affinity-purified anti- $\mathrm{P}_{\mathrm{C} 22}$ reacted with ribosomal $\mathrm{P}$ peptide-HSA conjugates, but not with $\mathrm{C} 22$ depleted rPO, confirming the lack of the C-terminal 22-amino acid sequence in the C22-depleted rPO (Figure 3). As shown in Figure 4, CSF anti-C22-depleted rPO levels were significantly correlated with CSF anti- $P_{\text {EX.C22 }}$ levels in these 65 patients. In addition, anti-C22-depleted rPO levels in CSF from patients with diffuse NP-SLE were significantly elevated compared with those from patients with focal NP-SLE or with noninflammatory neurological diseases (Figure 5). Accordingly, the frequency of positive expression of anti-C22-depleted rPO in CSF from patients with diffuse NP-SLE was higher than that in CSF from patients with focal NP-SLE or with non-inflammatory neurological diseases (Table 2). These results confirm the presence of autoantibodies to ribosomal $\mathrm{P}$ protein epitopes other than the C-terminal 22-amino acid sequence.

We next examined whether CSF anti-whole $\mathrm{P}$ might account for anti-N activities in CSF from patients with NP-SLE. As shown in Table 3, levels of CSF anti-whole $\mathrm{P}$ and anti-PC22 as well as CSF anti-N were decreased when CSF was incubated with paraformaldehyde-fixed SK-N-MC cells for 120 minutes at room temperature, confirming that CSF anti-whole $\mathrm{P}$ or anti-PC22 are constituents of CSF anti-N. However, as shown in Figure 6a, CSF anti-N levels were not significantly correlated with CSF anti-PC22 levels in SLE patients, including those with diffuse NP-SLE and focal NP-SLE. By contrast, CSF anti-N levels were significantly correlated with CSF antiPEX.C22 or CSF anti-C22-depleted rPO levels (Figure 6b,c

Finally, we examined serum levels of anti- $P_{C_{22}}$, anti-whole $P$, and anti-P $P_{\text {EX.C22 }}$ in patients with non-CNS SLE or with NPSLE. The values of anti- $P_{C 22}$, anti-whole $P$, and anti- $P_{E X . C 22}$ in 24 patients with non-SLE non-inflammatory neurological diseases were $2.44 \pm 2.92 \mu \mathrm{g} / \mathrm{ml}, 4.92 \pm 6.51 \mu \mathrm{g} / \mathrm{ml}$, and 3.41 $\pm 6.06 \mu \mathrm{g} / \mathrm{ml}$ (mean \pm standard deviation), respectively. As shown in Figure 7, serum anti- $\mathrm{P}_{\mathrm{C} 22}$ as well as anti-whole $\mathrm{P}$ lev-

Table 2

Summary of the frequency of positive expression of antibodies to various ribosomal $P$ protein components in cerebrospinal fluida

\begin{tabular}{lccc}
\hline & \multicolumn{3}{c}{ Percentage positive ${ }^{\mathrm{b}}$} \\
\cline { 2 - 4 } & Control & Diffuse NP-SLE & Focal NP-SLE \\
\hline Anti-P & $4.2 \%(1 / 24)$ & $23.1 \%(12 / 52)$ & $5.3 \%(1 / 19)$ \\
Anti-whole P & $0 \%(0 / 24)$ & $78.8 \%(41 / 52)$ & $31.6 \%(6 / 19)$ \\
Anti-P & $4.2 \%(1 / 24)$ & $65.4 \%(34 / 52)$ & $26.3 \%(5 / 19)$ \\
Anti-C22-depleted rP0 & $5.3 \%(1 / 19)$ & $44.7 \%(21 / 47)$ & $5.6 \%(1 / 18)$ \\
\hline
\end{tabular}

aAntibodies to the $\mathrm{C}$-terminal 22-amino acid sequence of ribosomal $\mathrm{P}$ protein (anti- $\mathrm{P}_{\mathrm{C} 22}$ ), to highly purified ribosomal $\mathrm{P}$ proteins (anti-whole $\mathrm{P}$ ), to the epitopes other than the C-terminal 22-amino acid sequence (anti-P $\mathrm{P}_{\mathrm{EX} 2}$ ), and to recombinant ribosomal P0 protein lacking the C-terminal 22 amino acid sequence (anti-C22-depleted rPO) in cerebrospinal fluid from patients with non-inflammatory neurological diseases (Control), with diffuse neuropsychiatric systemic lupus erythematosus (NP-SLE), or with focal NP-SLE were compared. bCutoff values were set as the mean +3 standard deviations of the values in control group. Values in parenthesis mean (numbers of patients with positive results/total patient numbers) in each group.

els in NP-SLE were significantly elevated compared with those in non-CNS SLE, which is consistent with previous studies [3-
5]. Serum anti- $P_{\mathrm{C} 22}$ and anti-whole $P$ levels appeared to be higher in diffuse NP-SLE than those in focal NP-SLE, although 
Figure 3

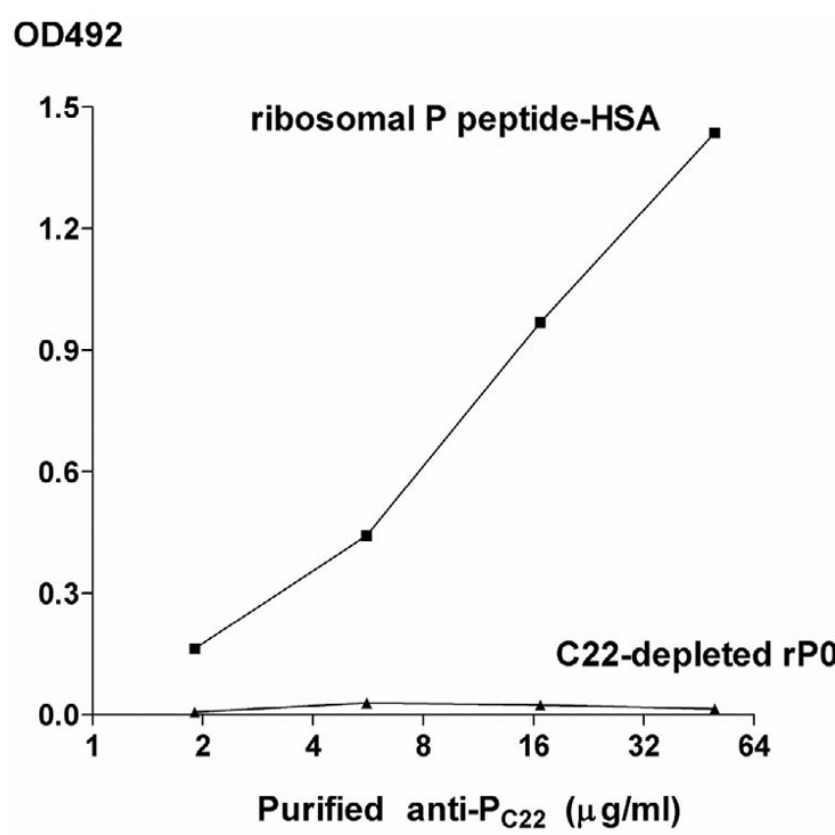

Differential reactivity of purified antibodies to the C-terminal 22 amino acids of ribosomal $\mathrm{P}$ protein. Differential reactivity of purified antibodies to the C-terminal 22-amino acid sequence of ribosomal $\mathrm{P}$ protein (anti$\mathrm{P}_{\mathrm{C}_{22}}$ ) with ribosomal $\mathrm{P}$ peptide-human serum albumin (HSA) conjugates and with recombinant ribosomal $\mathrm{PO}$ protein lacking the $\mathrm{C}$-terminal 22-amino acid sequence (C22-depleted rP0). Purified anti- $\mathrm{P}_{\mathrm{C} 22}$ react with ribosomal $\mathrm{P}$ peptide-HSA conjugates, but not with $\mathrm{C} 22$ depleted rPO on enzyme-linked immunosorbent assay plates. OD492 (optical density at $492 \mathrm{~nm}$ ) values that are subtracted by non-specific binding activities are plotted.

there were no statistical significances by Kruskal-Wallis test with multiple comparisons. Of note, there were no significant differences in serum anti- $P_{E X . C 22}$ levels between non-CNS SLE and NP-SLE. These results suggest that in contrast with the CSF results, serum anti- $P_{C_{22}}$, but not serum anti-P). The data therefore suggest that $\mathrm{C} 22$-depleted $\mathrm{rPO}$ might contain one of the major targets, against which CSF anti-N are directed. $_{\text {EX.C22, }}$ are associated with NP-SLE, especially diffuse NP-SLE.

\section{Discussion}

A number of studies have suggested that CSF anti-N play an important role in the pathogenesis of diffuse NP-SLE $[7,11]$. However, the epitopes to which CSF anti-N are directed have not been delineated. Of note, previous studies have demonstrated that epitopes antigenically related to ribosomal $\mathrm{P}$ proteins are present on the surface of SK-N-MC neuroblastoma cells [12]. Although anti- $P_{\mathrm{C} 22}$ have been shown to be major autoantibodies to ribosomal $P$ proteins $[3,4,22]$, the frequency of their detection in CSF from patients with diffuse NP-SLE was not high enough to ensure their involvement in the pathogenesis of this disease $[3,4,7]$. Therefore, it was suggested that anti- $\mathrm{P}_{\mathrm{C} 22}$ might not be a major constituent of anti-N in CSF from patients with diffuse NP-SLE. Consistently, the data in
Figure 4

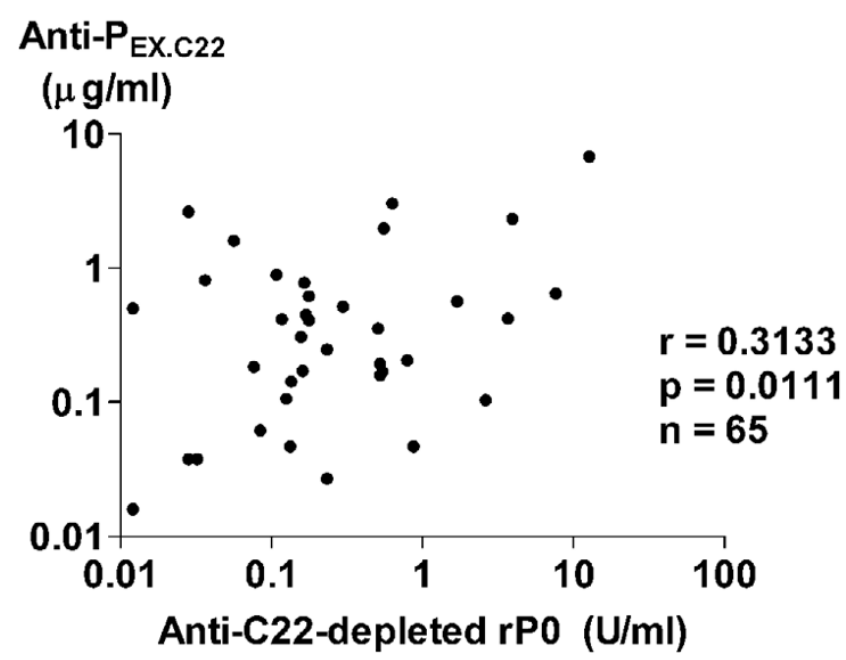

Correlation between autoantibodies to various components of ribosomal $\mathrm{P}$ proteins. The correlation between antibodies to recombinant ribosomal PO protein lacking the C-terminal 22-amino acid sequence (anti-C22-depleted $\mathrm{rPO}$ ) and those to the ribosomal $\mathrm{P}$ protein epitopes other than the C-terminal 22-amino acid sequence (anti- $P_{E X . C 22}$ ) in cerebrospinal fluid patients, including 47 patients with diffuse neuropsychiatric systemic lupus erythematosus (NP-SLE) and 18 patients with focal NP-SLE, was analyzed. Statistical analysis was performed by Spearman rank correlation test.

the current studies indicated that CSF anti- $P_{\mathrm{C} 22}$ levels were not significantly elevated in patients with diffuse NP-SLE compared with those in patients with focal NP-SLE or with noninflammatory neurological diseases. However, it was still possible that CSF autoantibodies directed to ribosomal $\mathrm{P}$ protein epitopes other than the C-terminal 22-amino acid sequence were more prevalent. Thus, the results in the current studies have also demonstrated that levels of CSF anti-whole $\mathrm{P}$ as well as CSF anti- $P_{E X . C 22}$ were significantly higher in patients with diffuse NP-SLE than in patients with focal NP-SLE or noninflammatory neurological diseases. The data therefore indicate that CSF antibodies to ribosomal $P$ protein epitopes other than the C-terminal 22-amino acid sequence are associated with diffuse NP-SLE.

To confirm the presence of antibodies for the epitopes representing regions of the ribosomal $\mathrm{P}$ proteins other than the $\mathrm{C}$ terminal 22-amino acid sequence, antibodies to recombinant ribosomal PO protein lacking the C-terminal 22 amino acids (C22-depleted rP0) [21] were evaluated. The results clearly demonstrate that CSF anti-C22-depleted rPO levels were significantly correlated with CSF anti- $P_{E X . C 22}$ levels. In addition, levels of CSF anti-C22-depleted rPO as well as CSF anti$P_{\text {EX.C22 }}$ were significantly elevated in diffuse NP-SLE. The data therefore confirm that CSF antibodies to ribosomal $\mathrm{P}$ protein epitopes other than the C-terminal 22-amino acid sequence play a role in the pathogenesis of diffuse NP-SLE, but further studies are required to identify the fine epitopes. 
Figure 5

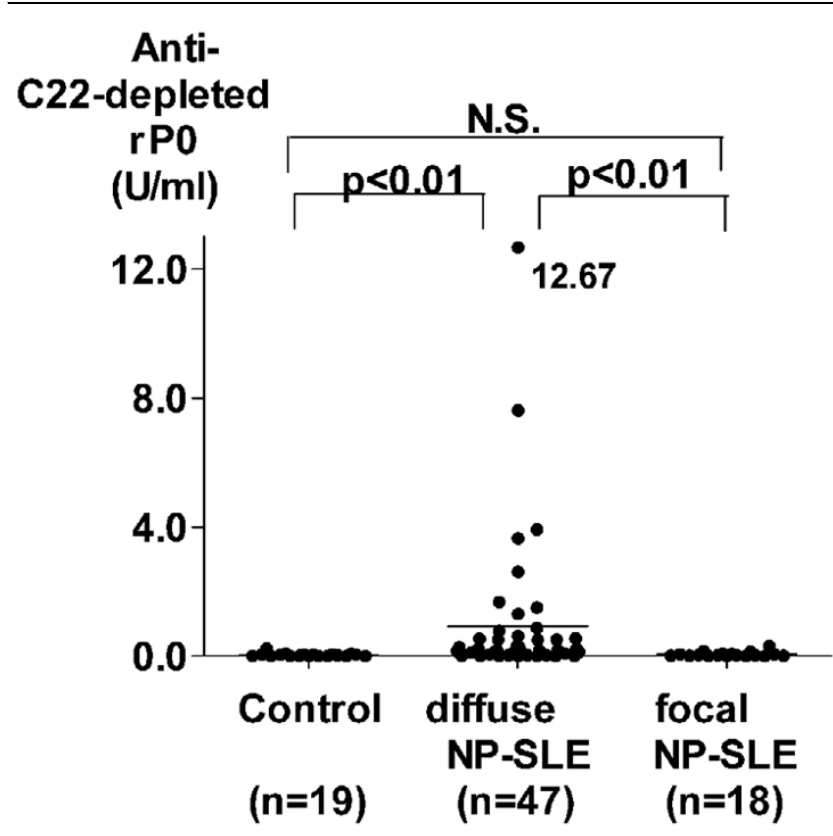

Cerebrospinal fluid antibodies to recombinant ribosomal P0 protein lacking the C-terminal 22-amino acid sequence. Antibodies to recombinant ribosomal $\mathrm{PO}$ protein lacking the $\mathrm{C}$-terminal 22-amino acid sequence (anti-C22-depleted $\mathrm{rPO}$ ) (U/ml) in cerebrospinal fluid from patients with non-inflammatory neurological diseases (Control), with diffuse neuropsychiatric systemic lupus erythematosus (NP-SLE), or with focal NP-SLE were compared. Horizontal lines indicate the mean values. Statistical analysis was performed by Kruskal-Wallis test with multiple comparisons (Scheffé's method). N.S., not significant.
In has been demonstrated that purified human plasma membranes contain a 38-kDa protein that is closely related or identical to ribosomal PO proteins [12]. Therefore, it was suggested that autoantibodies to ribosomal $P$ proteins, especially those directed to epitopes other than the C-terminal 22-amino acid sequence, might be involved (at least in part) in CSF anti-N activities. In fact, levels of CSF anti- $P_{\text {EX.C22 }}$ as well as CSF anti- $\mathrm{P}_{\mathrm{C}_{22}}$ or CSF anti-whole $\mathrm{P}$ were decreased after incubation of CSF with paraformaldehyde-fixed SK-N-MC cells, confirming that CSF anti- $P_{\text {EX.C22 }}$ as well as anti- $P_{\mathrm{C} 22}$ are constituents of CSF anti-N. However, CSF anti- $\mathrm{P}_{\mathrm{C} 22}$ levels were not significantly correlated with CSF anti-N levels in the present study. By contrast, CSF anti- $P_{\text {EX.C22 }}$ or CSF anti-C22depleted rPO levels were significantly correlated with CSF anti-N levels. These results indicate that ribosomal PO proteins contain one of the major targets of CSF anti-N in their portions other than the C-terminal 22-amino acid sequence. Of note, recent studies have demonstrated that autoantibodies directed against the $N$-methyl-d-aspartate (NMDA) receptor mediated apoptotic death of neurons in vivo and in vitro in murine systems [23]. Of note, anti-NMDA receptor antibodies were also detected in CSF from a single patient with SLE [22]. It is therefore likely that anti-NMDA receptor antibodies might also be involved in CSF anti-N activities and thus play a pivotal role in the pathogenesis of diffuse NP-SLE. Further studies with a large number of patients are required to confirm the involvement of anti-NMDA receptor antibodies in diffuse NP. SLE and to explore its relationship with anti-N.

A number of studies have indicated that serum anti-ribosomal $\mathrm{P}$ protein antibodies, including anti- $\mathrm{P}_{\mathrm{C} 22}$ or anti-whole $\mathrm{P}$, are

Table 3

Absorption of CSF autoantibodies to various components of ribosomal P proteins by neuronal cells

\begin{tabular}{|c|c|c|c|}
\hline Patient & Autoantibodies & Without absorption & With absorption \\
\hline \multirow[t]{4}{*}{1} & Anti-whole P ( $\mu \mathrm{g} / \mathrm{ml})$ & 7.243 & 1.435 \\
\hline & Anti- $P_{\mathrm{C} 22}(\mu \mathrm{g} / \mathrm{ml})$ & 3.456 & 1.019 \\
\hline & Anti-P $P_{\text {EX.C22 }}(\mu \mathrm{g} / \mathrm{ml})$ & 3.787 & 0.416 \\
\hline & Anti-N (U/ml) & 4.083 & 1.950 \\
\hline \multirow[t]{4}{*}{2} & Anti-whole P $(\mu \mathrm{g} / \mathrm{ml})$ & 0.140 & 0.050 \\
\hline & Anti- $P_{\mathrm{C} 22}(\mu \mathrm{g} / \mathrm{ml})$ & 0.070 & 0.042 \\
\hline & Anti-P $P_{\text {EX.C22 }}(\mu \mathrm{g} / \mathrm{ml})$ & 0.070 & 0.008 \\
\hline & Anti-N (U/ml) & 0.789 & 0.588 \\
\hline
\end{tabular}

Cerebrospinal fluid (CSF) samples (50 $\mu \mathrm{l} /$ well) were incubated in wells of a 96 -well flat-bottomed microtiter plate with or without confluent SK-N$\mathrm{MC}$ cells fixed with $1 \%$ paraformaldehyde at room temperature for 2 hours. After the incubation, CSF samples were recovered and were examined for anti-whole $\mathrm{P}$, anti- $\mathrm{P}_{\mathrm{C} 22}$, anti- $\mathrm{P}_{\mathrm{Ex}}$, and anti-N as described in Materials and methods. Anti-N, anti-neuronal cell antibodies; anti- $\mathrm{P}_{\mathrm{C} 22}$,

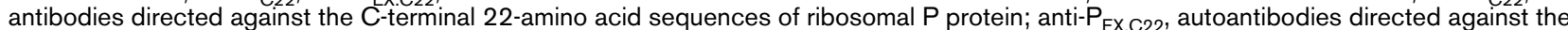
ribosomal $\mathrm{P}$ protein epitopes other than the $\mathrm{C}$-terminal 22-amino acid sequence; anti-whole $\mathrm{P}$, antibodies to the whole ribosomal $\mathrm{P}$ proteins.

frequently observed in patients with NP-SLE [3-5,24]. Consistently, the results in the current studies have also disclosed that levels of serum anti- $P_{\mathrm{C} 22}$ as well as serum anti-whole $P$ are significantly higher in NP-SLE than those in non-CNS SLE. Of 
Figure 6

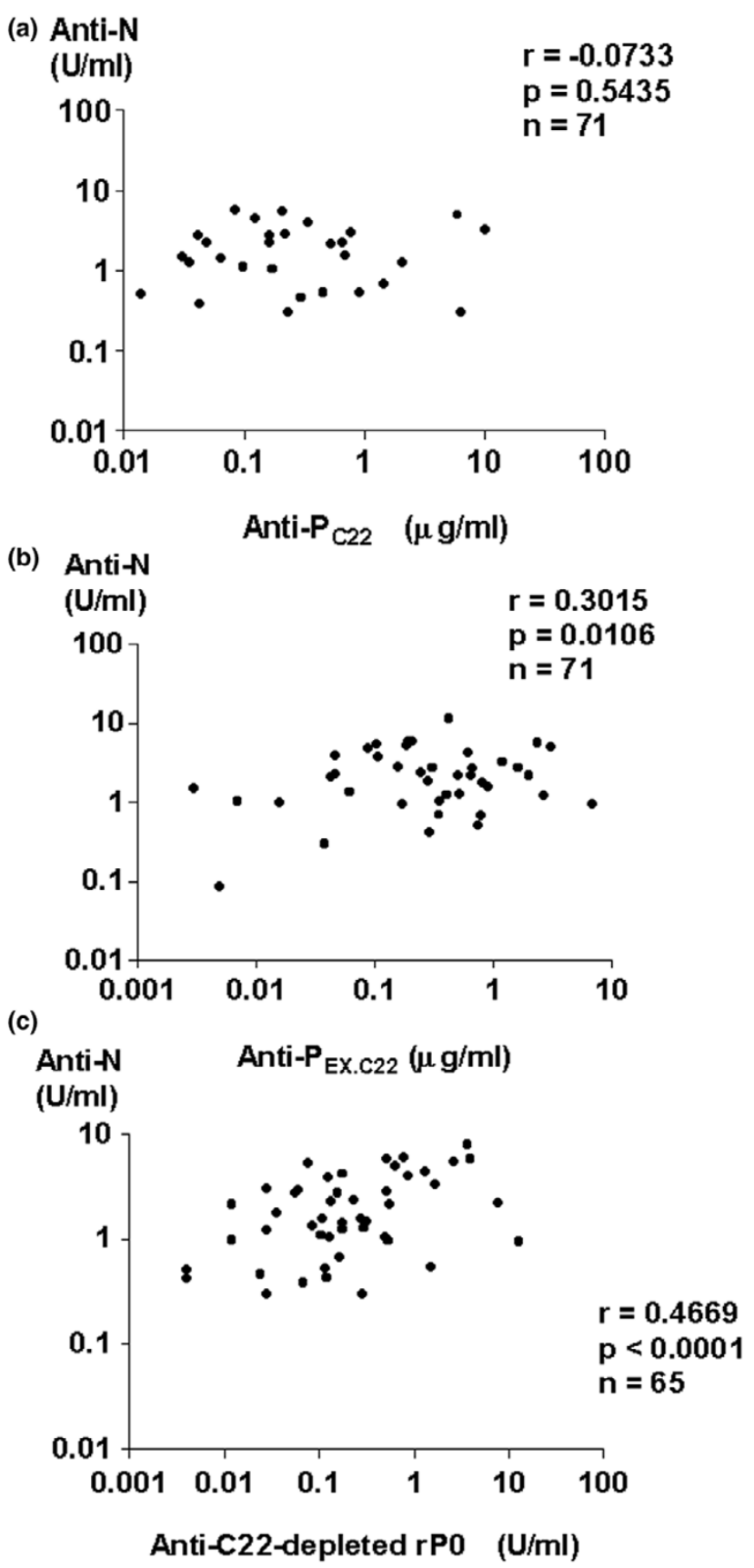

Correlation between autoantibodies to ribosomal $\mathrm{P}$ proteins and antineuronal cell antibodies. The correlation of antibodies to the C-terminal 22-amino acid sequence of ribosomal $P$ proteins (anti- $P_{\mathrm{C}_{22}}$ ) (a), those to the ribosomal $\mathrm{P}$ protein epitopes other than the $\mathrm{C}$-terminal 22-amino acid sequence (anti-P $\mathrm{EX.C22}_{2}$ ) (b), or those to recombinant ribosomal PO protein lacking the $\mathrm{C}$-terminal 22-amino acid sequence (anti-C22depleted rPO) (c) with anti-neuronal cell antibodies (anti-N) in cerebrospinal fluid from systemic lupus erythematosus (SLE) patients, including 52 patients $(a, b)$ or 47 patients (c) with diffuse neuropsychiatric SLE (NP-SLE) and 19 patients $(a, b)$ or 18 patients (c) with focal NP-SLE, was analyzed. Statistical analysis was performed by Spearman rank correlation test. note, serum anti- $P_{E X . C 22}$ levels were not significantly elevated in NP-SLE compared with those in non-CNS SLE. These findings contrast sharply with the results of CSF studies. Thus, in $\mathrm{CSF}$, anti- $\mathrm{P}_{\mathrm{EX} . \mathrm{C} 22}$, but not anti- $\mathrm{P}_{\mathrm{C} 22}$, were significantly associated with diffuse NP-SLE, whereas in serum, anti- $P_{\mathrm{C} 22}$, but not anti- $P_{\text {EX.C22 }}$, were associated with NP-SLE.

The mechanism by which anti-whole $P$ cause neuronal damage remains unclear. We previously reported that the expression of IL-6 mRNA in neurons was upregulated in the brain of an SLE patient who died of active diffuse NP-SLE [25]. Of note, we recently disclosed that anti- $\mathrm{P}_{\mathrm{C} 22}$ upregulate the expression of mRNAs for IL-6 and tumor necrosis factor-alpha in human peripheral blood monocytes [20]. It should be pointed out that anti- $P_{E X . C 22}$ as well as anti- $P_{C 22}$ might be able to bind the ribosomal $P$ protein on neuronal cells [12]. Taken together, these results suggest that anti-whole $P$ or anti$P_{\text {EX.C22 }}$ might also upregulate the expression of IL-6 mRNA in neurons and thus result in the alteration of their functions. Further studies to explore the targets and the effects on their functions of anti- $\mathrm{P}_{\mathrm{C} 22}$ and anti- $\mathrm{P}_{\mathrm{EX} . \mathrm{C} 22}$ (or anti- $\mathrm{P}_{\mathrm{AA} 9}$ ) would improve our understanding of the pathogenesis of NP-SLE.

In summary, the current studies have demonstrated that the expression of autoantibodies directed against the epitopes of ribosomal $\mathrm{P}$ proteins other than the $\mathrm{C}$-terminal 22-amino acid sequence is increased in CSF from patients with diffuse NP. SLE. The presence of such autoantibodies might account for CSF anti-N activities, although there might be other antibodies that bind to neuronal cells, such as anti-NMDA receptor antibodies. Further studies to explore the whole spectrum of epitopes of neurons to which autoantibodies are directed as well as the mechanism by which such autoantibodies cause damage to neurons are needed for a complete understanding of the pathogenesis of diffuse NP-SLE.

\section{Conclusion}

The present study has disclosed that CSF IgG antibodies to the epitopes of ribosomal PO proteins other than the C-terminal 22 amino acids are associated with the development of diffuse NP-SLE as one of the major CSF anti-N components.

\section{Competing interests}

The authors declare that they have no competing interests.

\section{Authors' contributions}

$\mathrm{SH}$ designed the study and participated in experimental procedures, collection, analysis, and interpretation of data and manuscript preparation. YA and MT contributed to the collection and analysis of data. TY helped to prepare C22-depleted rPO and to develop ELISA for anti-C22-depleted rPO. All authors read and approved the final text before submission of the manuscript. 


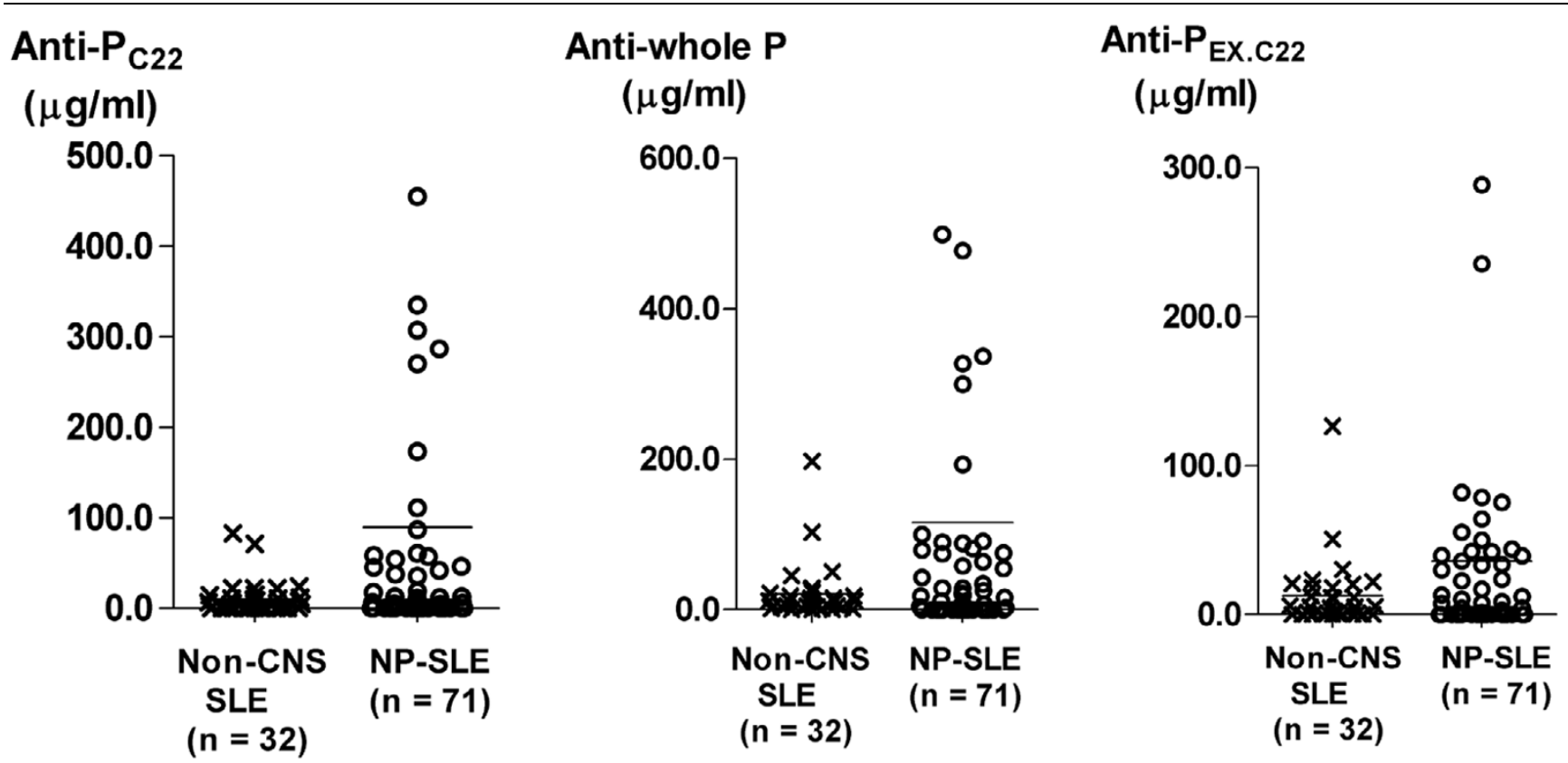

Serum autoantibodies to various components of ribosomal $P$ proteins. Anti- $P_{C 22}$, anti-whole $P$, and anti- $P_{E X . C 22}$ in sera from SLE patients without neuropsychiatric manifestations (non-CNS SLE) (cross), with diffuse NP-SLE (open circle), or with focal NP-SLE (closed circle) were compared. Horizontal lines indicate the mean values. Statistical analysis between non-CNS SLE versus NP-SLE (focal + diffuse) was performed by Welch's $t$ test. Anti- $\mathrm{P}_{\mathrm{C} 22}$, antibodies directed against the $\mathrm{C}$-terminal 22-amino acid sequences of ribosomal $\mathrm{P}$ protein; anti- $\mathrm{P}_{\mathrm{EX} . \mathrm{C}_{22} \text {, autoantibodies directed }}$ against the ribosomal $\mathrm{P}$ protein epitopes other than the $\mathrm{C}$-terminal 22 -amino acid sequence; anti-whole $\mathrm{P}$, antibodies to the whole ribosomal $\mathrm{P}$ proteins; non-CNS SLE, systemic lupus erythematosus without neuropsychiatric manifestations; NP-SLE, neuropsychiatric systemic lupus erythematosus; SLE, systemic lupus erythematosus.

\section{Acknowledgements}

This work was supported by 2005 grant (C2) no. 16590996 from the Ministry of Education, Culture, Science and Sports; a grant-in-aid from the Health Science Research grant from the Ministry of Health, Labor and Welfare of the Japanese government; and grants from Mitsubishi Pharma Corporation (Tokyo) and from Wyeth K.K. (Tokyo).

\section{References}

1. Gibson T, Myers AR: Nervous system involvement in systemic lupus erythematosus. Ann Rheum Dis 1975, 35:398-406.

2. Harris EN, Hughes GR: Cerebral disease in systemic lupus erythematosus. Springer Semin Immunopathol 1985, 8:251-266.

3. Bonfa E Golombek SJ, Kaufman LD, Skelly S, Weissbach H Brot $\mathrm{N}$, Elkon KB: Association between lupus psychosis and antiribosomal P protein antibodies. N Engl J Med 1987, 317:265-271.

4. Schneebaum AB, Singleton JD, West SG, Blodgett JK, Allen LG, Cheronis JC, Kotzin BL: Association of psychiatric manifestations with antibodies to ribosomal $P$ proteins in systemic lupus erythematosus. Am J Med 1991, 90:54-62.

5. Isshi K, Hirohata S: Association of anti-ribosomal P protein antibodies with neuropsychiatric systemic lupus erythematosus. Arthritis Rheum 1996, 39:1483-1490.

6. Golombek SJ, Graus F, Elkon KB: Autoantibodies in the cerebrospinal fluid of patients with systemic lupus erythematosus. Arthritis Rheum 1986, 29:1090-1097.

7. Isshi K, Hirohata S: Differential roles of the anti-ribosomal P antibody and antineuronal antibody in the pathogenesis of central nervous system involvement in systemic lupus erythematosus. Arthritis Rheum 1998, 41:1819-1827.

8. Bluestein HG, Zvaifler NJ: Brain-reactive Iymphocytotoxic antibodies in the serum of patients with systemic lupus erythematosus. J Clin Invest 1976, 57:509-516.
9. Wilson HA, Winfield JB, Lahita RG, Koffler D: Association of IgG anti-brain antibodies with central nervous system dysfunction in systemic lupus erythematosus. Arthritis Rheum 1979, 22:458-462.

10. Long AA, Denburg SD, Carbotte RM, Singal DP, Denburg JA: Serum lymphocytotoxic antibodies and neurocognitive function in systemic lupus erythematosus. Ann Rheum Dis 1990, 49:249-253

11. Bluestein HG, Williams GW, Steinberg AD: Cerebrospinal fluid antibodies to neuronal cells: association with neuropsychiatric manifestations of systemic lupus erythematosus. Am J Med 1981, 70:240-246.

12. Koren E, Reichlin MW, Koscec M, Fugate RD, Reichlin M: Autoantibodies to the ribosomal $\mathrm{P}$ proteins react with a plasma membrane-related target on human cells. J Clin Invest 1992, 89:1236-1241.

13. Fabien N, Moreira A, Lavergne JP, Desbos A, Surgey P, Alves de Olivera C, Gonzalo P, Venot A, Bienvenu J, Perrier $\mathrm{H}$, et al:: Autoantibodies directed against the ribosomal $P$ proteins are not only directed against a common epitope of the P0, P1 and P2 proteins. J Autoimmun 1999, 13:103-110.

14. Yoshio $T$, Hirata $D$, Onda $K, \mathrm{Nara} H$, Minota S: Antiribosomal $P$ protein antibodies in cerebrospinal fluid are associated with neuropsychiatric systemic lupus erythematosus. I Rheumatol 2005, 32:34-39.

15. Tan EM, Cohen AS, Fries JF, Masi AT, McShane DJ, Rothfield NF, Schaller JG, Talal N, Winchester RJ: The 1982 revised criteria for the classification of systemic lupus erythematosus. Arthritis Rheum 1982, 25:1271-1277.

16. ACR Ad Hoc Committee on Neuropsychiatric Lupus Nomenclature: The American College of Rheumatology nomenclature and case definitions for neuropsychiatric lupus syndromes. Arthritis Rheum 1999, 42:599-608.

17. Winfield JB, Shaw M, Silverman LM, Eisenberg RA, Wilson HA 3rd, Koffler D: Intrathecal IgG synthesis and blood-brain barrier impairment in patients with systemic lupus erythematosus 
and central nervous system dysfunction. Am J Med 1983, 74:837-844.

18. Hirohata $S$, Hirose $S$, Miyamoto $T$ : Cerebrospinal fluid IgM, IgA, and IgG indexes in systemic lupus erythematosus. Their use as estimates of central nervous system disease activity. Arch Intern Med 1985, 145:1843-1846.

19. Hirohata S, Miyamoto T: Elevated levels of interleukin-6 in cerebrospinal fluid from patients with systemic lupus erythematosus and central nervous system involvement. Arthritis Rheum 1990, 33:644-649.

20. Nagai T, Arinuma Y, Yanagida T, Yamamoto K, Hirohata S: Antiribosomal $P$ protein antibody in human systemic lupus erythematosus up-regulates the expression of proinflammatory cytokines by human peripheral blood monocytes. Arthritis Rheum 2005, 52:847-855.

21. Yoshio T, Masuyama J, Minota S, Iwamoto M, Mimori A, Takeda A, Okazaki $\mathrm{H}$, Kano S: Correlation of serum IgG antibodies to recombinant PO fusion protein with IgG antibodies to carboxyl-terminal 22 synthetic peptides and carboxyl-terminal 22 amino acid-depleted recombinant $\mathrm{PO}$ fusion protein in patients with systemic lupus erythematosus. Arthritis Rheum 1997, 40:1364-1365.

22. Elkon K, Skelly S, Parnassa A, Moller W, Danho W, Weissbach H, Brot $\mathrm{N}$ : Identification and chemical synthesis of a ribosomal protein antigenic determinant in systemic lupus erythematosus. Proc Natl Acad Sci USA 1986, 83:7419-7423.

23. DeGiorgio LA, Konstantinov KN, Lee SC, Hardin JA, Volpe BT, Diamond $B$ : A subset of lupus anti-DNA antibodies cross-reacts with the NR2 glutamate receptor in systemic lupus erythematosus. Nat Med 2001, 7:1189-1193.

24. Karassa FB, Afeltra A, Ambrozic A, Chang DM, De Keyser F, Doria A, Galeazzi M, Hirohata S, Hoffman IE, Inanc M, et al.: Accuracy of anti-ribosomal $P$ protein antibody testing for the diagnosis of neuropsychiatric systemic lupus erythematosus: an international meta-analysis. Arthritis Rheum 2006, 54:312-324.

25. Hirohata S, Hayakawa K: Enhanced interleukin-6 messenger RNA expression by neuronal cells in a patient with neuropsychiatric systemic lupus erythematosus. Arthritis Rheum 1999, 42:2729-2730. 